\title{
Evaluating the Challenges of IGAD-Led Peace Process of South Sudan
}

\author{
Mulugeta Birhanu Ephrem Ahadu \\ Department of Civics and Ethical Studies, Wachemo University, Po box 667, Hosaena, Ethiopia
}

\begin{abstract}
The purpose of study is to evaluate the challenges of IGAD-led peace process of South Sudan. Its objective is to evaluate and assess the challenges surrounding the South Sudan peace process mediated by the IGAD-led team. To address these objectives, the researcher employed qualitative research design to make use of its advantage in gaining detailed information about the issue, to examine reflections, understandings and knowledge of negotiators and refugees by offering an in-depth understanding of a particular problem and challenges. South Sudan became an independent state from the Sudan in July 9, 2011, following an internationally monitored referendum, which was held on 9 January. However, almost after three years of independence, the world newest state backslide into the horrific civil war on 15 , December 2013, due to the power rivalry within SPLM/A. The war resulted in the massive loss of human life and property destruction. Consequently, the regional organization, IGAD swiftly launched the peace process on Saturday 4th January 2014, in order to halt the crisis in South Sudan. Nevertheless, the peace process faced enormous internal and external challenges during the peace talk and also at present the Joint Monitoring and Evolution Commission (JMEC) is facing impediment in the implementation process. Based on the findings of this study, the researcher recommends the concerned bodies such as the IGAD, AU, IGAD-Plus and UN should exert pressure on both warring parties so as to speed up the implementation process of Peace Agreement because the South Sudanese are suffering by intense security problems and food crisis associated with the conflict up until now. Besides, the international community should keep out, those who are uncompromising and create impediment to the implementation of the peace accord, from the rank of Transitional Government of National Unity (TGONU). Because the evidences indicate that both belligerent parties leaders are not portrayed their political will and good faith to implement the Peace Concord.
\end{abstract}

Keywords: Conflict, Challenges, Conflict Resolution, Peace, Peace-building, South Sudan

DOI: $10.7176 / \mathrm{IAGS} / 78-01$

Publication date: December $31^{\text {st }} 2019$

\section{Introduction}

The recent conflict in South Sudan traced its origins back to the colonial past. The seeds of the wars have been sown by the Turko-Egyptian and Anglo-Egyptian colonial rulers that administrated North and South Sudan separately, which resulted in decades of civil wars between North and South Sudan (Yohannes, 2015:49). Therefore, the first civil war that broke out on August 18, 1955, during the eve of Sudan's independence from the Anglo-Egyptian administration on January 1, 1956 was to end for 17 years (Ibd, 3), in 1972, by signing the Addis Ababa Agreement, between the North and South, with recognizing the ethnic diversity of the Sudan. The Agreement granted the regional autonomy and comparative representation in the national assembly for South, however, in 1983 the second north-south war was to break out, when the government in part under pressure from Islamists, effectively abrogated the Addis Ababa Agreement by reversing the 1973 commitments on Islam and use of Arabic in the South as well as weakening the federal arrangement (Berghof Foundation for Peace Support, 2006:13; AUCISS, 2014).

The War was fought between the Sudan People's Liberation Movement (SPLM) of the South and the Northern government based in the capital Khartoum was brought to an end by the 2005 Comprehensive Peace Agreement (CPA) in Naivasha, Kenya. The agreement was brokered by the United States, several European countries and IGAD. The CPA sought to address many issues, such as power and wealth sharing, security arrangements etc, in spite of the label, it is not a comprehensive peace and it has not been able to stop armed conflicts within various regions of Sudan. While the war was declared ended in the south by the signing of the CPA (Abdelnour, etal 2008:7-8).

The CPA agreement established a six-year interim period, beginning July 9th 2005, where Southern Sudanese would govern their own regional affairs and participate equally in the national government (Daoud, 2012:45). The agreement also specified an important provision for referendum in 2011, to determine whether the majority of the southern populations will have opted to split the southern territories from the north or remain united (Abdelnour, etal 2008:8). Accordingly, the southerners were disposed to secession due to the poor implementation of CPA on many fronts and other above-mentioned factors. On February 14th 2011, the first official referendum results were declared. As expected, the South Sudanese overwhelmingly voted for partition. On July 9th, the South Sudan celebrated its official independence from Sudan forming The Republic of South Sudan, Africa's newest state (Daoud, 2012:49). 
However, nearly after three years of independence South Sudan relapse into civil war on 15 December 2013 because of the power struggle within the SPLM/A, which later escalated into violence conflict and mass killing. The violence has largely been committed by Sudan People's Liberation Army (SPLA) and the Sudan People's Liberation Movement/Army in Opposition (SPLM/A-IO), with both sides using armed groups and militias in the conduct of hostilities.

In an attempt to stop this crisis, the Inter-Governmental Authority on Development (IGAD), immediately launched the peace talk by selecting the three envoys such as Seyoum Mesfin of Ethiopia, Lazarus Sumbeiywo of Kenya and Mohammed El Dhabi of Sudan. As a result, the IGAD-led mediation of first round talks between the warring parties was held in the Ethiopian capital, Addis Ababa, on Saturday 4th January 2014. But the IGAD-led mediation of peace process later declared into IGAD-Plus, (which included the Troika countries (USA, UK and Norway), the UN, the AU, the EU, China and the IGAD Partners Forum (IPF) because of the team was faced various internal and external challenges during the peace process. Nevertheless, the belligerent parties eventually were signed the peace agreement in August 2015, due to the IGAD-Plus pressure.

Therefore, this document has assessed the internal and external challenges that the IGAD-facilitated peace process of South Sudan confronted during the peace talk and the prospects of peace agreement in ensuring lasting peace for South Sudanese. The paper also to some extent examined the ongoing process of implementation of peace agreement led by Joint Monitoring and Evaluation Commission (JMEC).

\section{Statement of the problem of the study}

South Sudan declared its independence in July 2011, after the protracted civil wars with Sudan. But almost after the three years' independence, the world newest nation was dragged to the brutal civil war in December 2013, which caused enormous death, destruction and displacement of the people of South Sudan which triggered by power struggle within SPLM/A.

According to, (Gil, 2014:4) the SPLM convened its Second National Convention in 2008, which was the first since the signing of the Comprehensive Peace Agreement (CPA). In that conference, symptom of power struggle appeared as Riek Machar wanted to compete for the SPLM chairmanship, a position that would make him president in the 2010 expected elections. But President Salva Kiir desired to maintain his position. These circumstances precipitated to violent conflict that broke out in South Sudan in July 2013. The political turmoil launched when President Salva Kiir announced a chief cabinet reshuffle in which Vice-president Riek Machar and Pagan Amum, the Secretary General of the Sudan People's Liberation Movement (SPLM), and other key officials were abdicated from office. This political action demonstrated the apparent fissure within the Sudan People's Liberation Movement. The dismissed leaders of SPLM in their part charged in press conference President Kiir of using repressive behavior violating the party and national constitutions. After long postponement National Liberation Council was held on 14 December where President Kiir again approved Pagan Amum's dismissal and abolition of secret balloting. The dismissed officials and their followers refused the next day session, and then the armed conflict started that evening between the Nuer and the Dinka factions of the presidential Guard in Juba.

Following this crisis the IGAD quickly convened an emergency summit of the Assembly of Heads of State and Government on December 27, 2013 in the Kenyan capital Nairobi. As anticipated, this meeting helped in forging what was chiefly regarded, and rightly so, as a critical regional response to the crisis, basically showing its commitment to mediate between South Sudan's warring parties. To immediately start the envisaged mediation process, the summit ensured that Seyoum Mesfin of Ethiopia, Lazarus Sumbeiywo of Kenya and Mohammed El Dhabi of Sudan were chosen as exceptional emissaries (Akol, 2014:3).

Subsequently, the first round of peace talks between the warring parties began in January 2014 (Ibid), a few weeks after the fighting broke out, hosted by regional bloc in Addis Ababa, Ethiopia, the talks were focused on attempts to immediately end the fighting and all the death and obliteration that it was causing (Blanchard, 2014:1). In consequence of, on 23 January 2014, the cessation of agreement was signed between the parties in conflict, in order to halt the conflict and fighting between them. However, the regional rivalries and power struggles; the centralization of decision-making at the HoS level and associated lack of institutionalization within IGAD as we as the expanding peace process beyond South Sudan's political elites were the major factors which remain challenges and limited IGAD's mediation efforts (International Crisis Group, 2015:i).

Despite the signing of the cessation of hostilities between the warring parties, the peace process was unsuccessful in ending the conflict and fighting between warring parties. Because the unwillingness of the two Antagonist parties to respect what they have pledged and signed for in the peace deals as it was seen in their repeated backslid into conflict. Accordingly, Later IGAD- PLUS was declared in March 2015 following the fifteen months of unsuccessful mediation of the crisis (International Crisis Group, 2015:3). The IGAD-PLUS' approach to the mediation is shaped by two reasons: firstly, that the parties are unwilling to come to an agreement without pressure and secondly, that IGAD would need to call on the weight of the wider international community to exert the necessary pressure in a coordinated manner (International Crisis Group, 2015:4). 
Therefore, the researcher wants to evaluate the internal and external challenges that the IGAD-led peace process of South Sudan faced during the peace mediation and at present the Joint Monitoring and Evaluation Commission facing in the implementation process of the peace Agreement as well as to examine the reflections of different participant and concerned bodies concerning the stumbling blocks as well as the overall circumstance of the peace process of South Sudan.

\section{Objectives \\ General objective}

The general objective of this study is to inquiry and understands the challenges of IGAD-led peace process of the South Sudan during peace deal and in the implementation phase of Peace Agreement by Joint Monitoring and Evaluation Commission (JMEC) and to examine and assess the reflections of different stakeholders and participants regarding the stumbling blocks of peace procedure.

\section{Specific Objectives}

- To indentify and analyze the internal and external challenges of IGAD-led peace process of South Sudan during the peace negotiation.

- To assesses the impediments that Joint Monitoring and Evaluation Commission (JMEC) facing in the implementation process of the Peace Agreement.

- To examine the reflections of various participants and stakeholders concerning the stumbling blocks as well as to evaluate the overall circumstance of the peace process of South Sudan.

\section{Research Questions}

This study addressed the following research questions: -

- What are the internal and external challenges of IGAD-led peace process of South Sudan during peace talks?

- What are the obstacles which Joint Monitoring and Evaluation Commission (JMEC) confronting in the implementation process of Peace Accord?

- What are the reflections of different interlocutors and concerning bodies about the stumbling blocks and overall scenario of peace process of South Sudan?

\section{Significance of the Study}

It is important in creating awareness about the challenges that the IGAD-led mediation team faced during the peace process in South Sudan present conflict resolution. Moreover, the study gives knowledge about the challenges in the implementation process of peace agreement as well as the prospect of peace agreement in ensuring sustainable peace in the South Sudan by Joint Monitoring and Evaluation Commission (JMEC).

Furthermore, the study serves as a reference for other researchers, academicians, practitioners, government and non-governmental organizations in future investigation particularly for those who are interested in conflict resolution activities.

\section{Scope of the study}

It is limited in terms of trying to map and evaluate the challenges of IGAD-led Peace process of South Sudan during the peace talk and up to the initial stage of the implementation of the peace agreement by Joint Monitoring and Evaluation Commission (JMEC).

\section{Research Methodology \\ Research Design}

The researcher employed qualitative research design. The reason for choosing qualitative research design is mainly because of its advantage in gaining detailed information about the issue, as stated by Creswell (2007). Qualitative research is also concerned with qualitative phenomenon i.e phenomena relating to quality rather than quantity and it is also concerned with subjective assessment of attitudes, opinions and behavior (Kothari, 2004:5). Therefore, this research method helped the researcher to explore reflections, understandings and knowledge of negotiators and refugees by offering an in-depth understanding of a particular problem and challenges rather than presenting it with numerical representation.

The purpose of this research has been to explore and assess the challenges that IGAD-led mediation faced during the peace process and in the implementation stage of peace agreement. Hence, this research is descriptive research. According to Kothari (2004:2) the major purpose of descriptive research is description of the state of affairs as it exists at present and fact finding enquiries of different kinds. Descriptive research sets out to describe and to interpret what is or was. It looks at individuals, groups, institutions, methods and materials in order to describe, compare, contrast, classify, analyze and interpret the entities (Abiy, et al 2009). 
Therefore, the researcher selected and employed this method to report the challenges that the IGAD-led mediation team has confronted during the peace process and at present in the implementation stage the Joint Monitoring and Evaluation Commission (JMEC) is facing.

\section{Sampling Techniques and Sample Size}

Purposive sampling method was used to select research participants who were concerned persons of the study. According to Patton (2002) Purposeful sampling is a technique widely used in qualitative research for the identification and selection of information rich cases for the most effective use of limited resources as cited by Palinkas, et al (2013:2). In other word, purposive sampling is also known by different names such as Nonprobability sampling, deliberate sampling and judgment sampling. In this kind of sampling, items for the sample are selected deliberately by the researcher (Kothari, 2004:59). This sampling technique was used as a means to select research participants. This was purposively done in order to understand the reflections, understanding and knowledge of negotiators and refugees that owned in the peace process in depth.

Moreover, the researcher used snowball sampling method in order to get knowledgeable and experience participant in the peace process. Snowball sampling (also called network, chain referral, or reputational sampling) is a method for identifying and selecting the cases in a network. It begins with one or a few people and spreads out on the basis of links to the initial cases or one research participant refers another, and that person refers another, and that person refers another. According to Berg (2001) Snowballing is sometimes the best way to locate subjects with certain attributes or characteristics necessary in a study. The researcher got the research participants in this way to conduct in-depth interview.

Therefore, totally ten participants were participated in this interview through face-to-face interview and email interview. The participants were selected from different categories of stakeholders in the peace process (i.e. from the government, the opposition, the IGAD, the civil societies and the refugees).

\section{Data Collection Methods}

Relevant data were obtained from primary sources and secondary sources. According to Kothari (2004:95) primary data are those which are collected afresh and for the first time, and thus happen to be original in character. Hence the methods of gathering primary entail; interview, observation, questionnaires, content analysis and etc. primary data was gathered through in depth interview. In depth interview is appropriate to gather data in detail for the qualitative research as Suggested by Creswell (2007).

Moreover, the researcher extensively used secondary sources such as books, thesis, journals, agreement documents and reports. Secondary data means data that are already available i.e. they refer to the data which have already been collected and analyzed by someone else (Kothari, 2004:95). Therefore, the research tried to consult these sources to compile this study.

\section{In-depth Interview}

Scholars like Denzin (1978) and Spradley (1979) as cited by Bruce (2001) define interview as simply as a conversation with a purpose of gaining information. The primary purpose is to gain relevant information from the stand point of the research objective and to gain constructive view from participants in the research.

It is often used as a method of generating data for understanding people's knowledge, experiences, opinions, beliefs, needs, perceptions, and constraints. It can be categorized as structured, semi-structured or unstructured in their settings (Robson, 1993). Therefore, the researcher conducted in depth interview with selected participants who were participated in the peace process and other stakeholders. Triangulations were used to make the data more credible and valid, crosschecking information from different stakeholder and participants in the peace process (Government, Opposition, Refugees, Civil societies and IGAD). Hence, the researcher interviewed different individuals using the interview guidelines to triangulate the data from different directions. In-depth interviews were conducted with ten key informants. These in depth interview participants were selected purposively based on their knowledge and understanding they have in the peace process.

\section{Data Analysis}

The researcher analyzed the data by using qualitative method in a thematic way. For this purpose, the researcher follow certain steps first the researcher recorded all interviewees' voice by tape record during data collection and later the researcher transcribed manually after repeatedly listening recorded voice of interviewees. For the purpose of accuracy of data analysis, codes were given to each research participants by giving pseudonyms or false names for actual participants for anonymity in this stage.

Second stage was separating and extracting significant statements that pertain directly to the peace process. In this stage of analysis, the transcripts were read and reread to separate words and sentences of participants' reflection on the peace process using color by highlighter pen to identify significant words, phrases and statements of particular participants during transcribing 
on hard paper.

Third step of data analysis was formulating meanings for significant statements. Under this stage the researcher sorted similar ideas of in depth interview participants to formulate meanings of peace process based on highlighted significant statements of participants. Fourth step of data analysis was categorization of formulated meanings of peace process. In this stage the researcher formed sub themes to write analysis of peace process and the researcher did accordingly. Following the thematic area the entire data transcripts were rearranged. This is because Strauss, et al (1998) argued that events, happenings, actions/interactions that are found to be conceptually similar in nature or related in meaning are grouped under more abstract concepts which are termed as categories.

Fifth stage of analysis was integrating the findings into thorough description of the fact being studied. In this stage, the already arranged and organized data were set to be analyzed by triangulation the data which were gathered by two major methods such as primary and secondary sources. Because triangulation increases validity by incorporating several viewpoints and methods in social science research as stated by Sabina, et al (2012). Social science reality is so complex that it is impossible to be captured by a single way of data collection or technique that needs triangulations of data analysis from different sources. According to Patton (2002), triangulation strengthens a study by combining different methods. Hence, the researcher analyzed data by triangulation from primary and secondary sources.

The findings from these two sources were integrated in places where it is necessary by describing the fact of the peace process. Analysis of data was made by giving greater emphasis for subjective reality of participants' experiences in the study.

\section{Analysis and Interpretation The beginning of the peace process of South Sudan}

Following the spoiling for a fight broke out in December 2013, the Intergovernmental Authority on Development (IGAD), a regional organization swiftly mandated three mediators to broker a peace deal between Salva Kiir and Riek Machar (Koos, et al 2014:2). But Starting from July of 2013, when Salva Kiir disband his entire cabinet, a number of initiative have been in place, it was very clear from that point on that if he sacked his entire cabinet, will be possibility that they going to run travel is extremely high. So from the very beginning there was moves within the region mostly bilateral moves between the countries of the region, many mission that went to South Sudan, they tried that Salva, what he just did, so that conversation was going on, so there was some initiative almost bilateral between countries. Because, Dr. Tewodros Adhanom went there some point and another conversation was made with Uhuru kenyata is there just tried and get Salva Kiir specifically more about the decision had made.

So the first move would be around December 17, 2013, when Dr. Tederowos Adhanom, the Ethiopia Foreign Minister, under the IGAD council of ministers went down to Juba to understand from Salva Kiir various issues especially focusing on his initiation to resolve the conflict as soon as possible. This was very fast initiative after 15 December 2013. On 26 December, 2013 his excellence, Haile Mariam Desalegn the chairman of IGAD and his excellence Uhuru Kenyata the rapporteur of IGAD went to South Sudan. Therefore, the evidences indicated that there were aforementioned initiatives before IGAD started the peace talk.

Thus, the peace process was launched as a result of the outbreak of the conflict in South Sudan. Following the outburst of fighting, IGAD quickly convened an emergency summit of the Assembly of Heads of State and Government on December 27, 2013 in the Kenyan capital Nairobi. As anticipated, this meeting helped in forging what was chiefly regarded, and rightly so, as a critical regional response to the crisis, basically showing its commitment to mediate between South Sudan's warring parties. To immediately start the envisaged mediation process, the summit ensured that Seyoum Mesfin of Ethiopia, Lazarus Sumbeiywo of Kenya and Mohammed El Dhabi of Sudan were chosen as exceptional emissaries (Akol, 2014:3).

Besides the selection of the said peace envoys, the IGAD December summit also highlighted the need to have an inclusive peace process. Subsequently, the peace talks between the warring parties began in January 2014 (Ibid), a few weeks after the fighting broke out, hosted by regional bloc in Addis Ababa, Ethiopia, the talks were focused on attempts to immediately end the fighting and all the death and obliteration that it was causing (Blanchard, 2014:1). IGAD Council of Ministers met in the Kenyan capital, Nairobi, on 27th December 2013, and called for an IGAD-led peace process for South Sudan, and the first round of the talks was held in the Ethiopian capital, Addis Ababa, on Saturday 4th January 2014.

Therefore, the Negotiators to the South Sudan Peace Talks were mainly: The warring parties, the Government of the Republic of South Sudan and the SPLM-SPLA in Opposition. They were the first parties to the peace talks. Later the Former Political Detainees were included, and then the other stakeholders: the Faithbased group made up of religious leaders from the South Sudan Council of Churches (SSCC) representing Christians and leaders from the South Sudan Islamic Council representing Muslims in South Sudan. Also the civil society organizations (CSOs) from South Sudan (those under government controlled areas) and those under 
the Opposition's controlled area, and those from the Diaspora were also allowed to take part in the negotiations. Other participants included the Women's Bloc, Eminent Personalities from South Sudan. Generally, there were seven groups of participants and the total number of participants was about "89" delegates all together.

\section{The Agendas of Peace Process}

Almost all interviewees responded that the agenda of the peace process are formulated by IGAD-mediators together with the parties to the conflict. Hence, as one respondent from civil society alluded that the agenda included negotiations to end the conflict, study of the root causes of the conflict, how did the war start, and what would be the solution to the conflict. The agenda produced an Agreement called "Agreement on the Resolution of the Conflict in the Republic of South Sudan". On the other hand, the interviewee from the government side noted that the main agenda should bring peace to South Sudan. But in order to bring peace for South Sudan they have to understand each party, their demands and points of conversation or points of agreement. The agenda which was presented supposed to reform institutions, cessation of hostilities and ceasefire and open corridors of humanitarian system.

On the contrary, also from the opposition side stated that the SPLM/A in opposition were looking for federal system. They want the federal system to be incorporated in hand to reach the peace agreement. Secondly, they need the reform for all government institutions. The third one is, they need the government to pay money for those who were killed and the property that were damaged in the war. Lastly, the SPLM/A in opposition needed two separate army force.

On the one hand, the respondent from the civil society's side noted that the efforts were to convince the warring parties to cessation of hostilities, to stop fighting and to negotiate. This is the main issue during the peace process.

According to Fok (2014:5) from the beginning what was important was to cease the killings. As a result, the government delegation to the Addis Ababa-based negotiations demanded on the talks being limited to the warring parties that the quickest way to end the violence was a direct dialogue between the government and the opposition. But the rebels, the donors and the civil society organization pushed for an inclusive approach. The oppositions were at this time talking about change in power, and justice and accountability for the incident of violence that took place in Juba when the fighting broke out. Further, the insurgent talk about political strategies of each party, with opposition underscoring a commitment to institutional reforms, democracy, tackling corruption and changes in the system of governance (Ibid).

Therefore, the issue of approval of the peace agenda by the both parties is very controversial, because the respondents react different views. Some say that the agendas were accepted by both parties and the other say that the agenda were not accepted particularly by the government. As one of interviewee from the government side says that both parties want peace in any conflict, they want to have peace that is favor to their terms but what it mean the peace agreement that it been signed really to be honesty trying, was not acceptable by the government and even by the opposition parties, because the people were pressure to sign it, so it sign the parties prefer that to be given negotiate, so that they get peace agendas that they can be happy to sign and be happy to implement. This always imposed because the mediators under pressure, the parties to the conflict under pressure, the region under pressure and the continental organization under pressure, so they have to sign it. However, as one of interviewee from the civil societies side described that the agenda items presented were accepted by the parties because they participated in drafting these agenda items.

In addition, one of the respondents alluded that they negotiated and discussed. They had negotiators, there were observers and the civil societies members. The inclusivity is there and it is clear. The inclusivity was achieved through study of influential groups in the country. This helped in the negotiation process during and outside roundtable talks. There were attempt to influence the two warring parties on the issue of cessation of hostilities and then gradually the government made an agreement on August 26, 2015.

\section{The Challenges of the Peace Process}

The peace process faces numerous internal and external challenges before and after signed the "Agreement on the Resolution of the Conflict in the Republic of South Sudan". According to, Yohannes (2015:52) challenges that destabilize the efforts of solving the conflict before reaching to an agreement was the unwillingness of the two Antagonist parties to respect what they have pledged and signed for in the peace deals as it was seen in their repeated backslid into conflict. As one interviewee from civil society said that much of the reason for the delay of peace agreement was the internal factor, which is lack of trust and the absence of give and take spirit, this zero sum game type of thing in both of the leaders of the warring parties. It was disheartening. According to him that there was no any serious outside challenge, although the Ugandan army was there to uphold the government side. But this was not mean much they insisted that to protect the capital city from falling apart say that they were doing a middleman's jobs and so on, but it was difficult, however, it was not the most serious external challenge. He noted that there was no visible and serious outside challenge. The main challenge came from intransigence 
and inflexibility of the warring parties leaders, who knew each other more than anyone else. They became very stubborn.

Additionally, among the eleven political detainees the rest four are remained in detention and under trial of treason which is detrimental for solving the conflict. The other challenge was existence of various armed opposition groups often with competing interests and the need to accommodate their interests in the mediation agenda so as to outcome an all-inclusive lasting solution for the conflict makes the mediation efforts challenging (Yohannes, 2015: 52).

Moreover, the fright of being accountable for the ethnic killing leaders in the top rank caused in their past and present contention for power might constrain their genuine commitment to find solution for the conflict (Ibid). According to Awolich (2015:7) the serious challenges to the IGAD mediation had been the fact that the mediators did not simply understand the power of momentum and the mediation seemingly suffered from lack of full mandate and independence. This is assumed from the fact that the mediators hardly tried to resolve any stalemates with the parties. Instead, they consulted the Heads of State and Government whenever hurdles were hit.

The other challenges were the contending interests and different ways of the IGAD member states pursued beyond the IGAD-led mediation process against the efforts to solve the conflict, particularly those who involved in the peace process (Ethiopia, Kenya, Sudan and Uganda). So there was no unity among IGAD member states during the peace process (Yohannes, 2015: 52).

Furthermore, the other problem was on power sharing the government initially wanted $70 \%$ of the ministerial portfolios in the transitional government of national unity, whereas the SPLM-SPLA in Opposition wanted $70 \%$ too. But they were pressured to make compromises which indeed they made and came to accept $53 \%$ for the Government and 33\% for the SPLMSPLA in Opposition, and the former Political Detainees, and the other political parties were given each $7 \%$ of power sharing in the Transitional Government of National Unity.

Additionally, on the side of the Government, President Salva Kiir issued a decree in December 2015, creating 28 new states which contradict the provisions of the Peace Agreement that recognizes ten states. Therefore, the SPLM/A-in Opposition and the international community rejected the creation of the 28-states because they violate the provisions of the Peace Agreement. The Intergovernmental Authority on Development (IGAD), the regional political bloc that supervises South Sudan's peace talks, on 31 January 2016, asked the GRSS to suspend its plan to implement the 28 states, claiming that Kiir's decree was contradictory with the August peace agreement (HSBASSS, 2016:4).

Internally also the government did not withdraw its forces outside the National capital Juba, as stipulated in the Peace Agreement. In the agreement all military forces within Juba shall be redeployed outside a radius of $25 \mathrm{~km}$ from the center of the national capital beginning thirty days after the signing of this Agreement and complete after ninety days (IGAD, 2015: 24). Juba the national capital of South Sudan was supposed to be demilitarized after the signing of the Agreement by the Parties, but did not happen because the government did not withdraw the forces outside the capital.

Moreover, according to Mogae (2016:2) the chairperson of Joint Monitoring and Evaluation Commission (JMEC) report that the pre-transitional period of 90 days provided in the Agreement ended without the formation of the Transitional Government of National Unity (TGoNU) due to the absence of the SPLM/A-in Opposition from the first meeting of JMEC on 27 November 2015. During that time, they had not returned to Juba for several reasons including a dispute between the Parties over the size of the advance team delegation contributed to the Commission's inability to meet quorum. Unfortunately, disputes over the representation of other political parties continue to limit the inclusiveness of representation in the process envisaged by the Agreement. Other political parties remain unrepresented at JMEC as well as in other key institutions where their participation was foreseen.

The other major disagreement was on the power sharing between the government and the First Vice President during the Transitional Period. The President cannot take decisions without consulting the VicePresident. During the Transitional Period, on the side of security arrangements the Opposition wanted to have two separate armies. The government wanted one unified army. The Opposition said they don't trust the government and the army in Juba, which has killed civilians in Juba, Malakal, Bor and Bentiu during the time when the conflict broke out on 15th December 2013. So the Opposition wanted to have two-armies during the transitional period. They said its army would guarantee the implementation of the Peace Agreement and avoid the government abrogate the agreement. While the government on the contrary couldn't accept separate armies, and accused the Opposition of a plan to stage a rebellion. Eventually, this stalemate was settled during the IGAD-PLUS mediation, they agreed to have two separate armies during the 30-month-transitional period.

Therefore, IGAD-PLUS' approach to the mediation is shaped by two reasons. Firstly, that the parties were unwilling to come to an agreement without pressure and secondly, that IGAD would need to call on the weight of the wider international community to exert the necessary pressure in a coordinated manner (International Crisis Group, 2015:4). IGAD-PLUS was announced in order to give maximum pressure to the warring parties. 
Indeed, it was because of IGAD-PLUS that was why the parties were able to reach a peace agreement by the 17th August 2015.

Externally, the parties to the conflict accused foreign forces of interests in South Sudan conflict. Parties accused regional powers such as Sudan and Uganda of involvement in the conflict. Sudan was accused by the government of South Sudan of supporting the armed opposition (The SPLM-SPLA in Opposition), and the SPLM-SPLA in Opposition accused Uganda of involvement in South Sudan conflict by openly supporting the South Sudan Army (SPLA) with backup from the Ugandan People's Defense Forces (UPDF). Because of their entrenched and incompatible interests, the roles of Sudan and Uganda in the peace process have been disparaging to IGAD's mediation efforts in South Sudan (Getachew, 2015:2).

During the peace process, even though all above mentioned obstacles faced, they were signed the peace agreement. The SPLM/A in Opposition signed on 17 August 2015, whereas the government on 26 August 2015.

\section{The Success of Peace Process}

There were all seventh round of peace talks split in different sessions held mainly in Addis Ababa and Bahir Dar town of Amhara region. The talk was held as from 4th of January 2014 to 17th August 2015.One of the respondent from the government side noted that the agenda was all about peace, stop fighting, open humanitarian corridors, return refugees and form the government for national unity.

Thus, the success of the IGAD-led mediation endeavors and the international pressure is that a cessation of hostilities agreement was signed between parties on 23 January 2014 who agreed to cease the war and hostile propaganda to each other and protection of civilian and also the parties agreed to form a Monitoring and Verification Mechanism (MVM) under the leadership of IGAD (IGAD, 2014:3-4). Moreover, the parties were signed an agreement on the status of detainees, who committed to effort to speed up the release of the political detainees, an all-inclusive dialogue and National Reconciliation Process to provide enduring solution for the conflict (IGAD, 2014). On 9 May 2014, the two parties in conflict was signed a peace agreement, they agreed to stop all hostile activities within 24 hours and also agreed that a transitional government of national unity will offer the best chance for the people of South Sudan to take the country forward (IGAD, 2014:2).

According to Yohannes (2015:51) the IGAD-led mediation efforts have born some successes that comprise: the release of seven of the eleven political detainees and allowed them to join the peace talks in Addis Ababa in February and from 6-7 June 2014, an inclusive IGADled symposium was held in Addis comprised over 250 South Sudanese representing the government, the opposition, political parties, faith-based groups and civil society organization meant to initiate the inclusive phase of the mediation process. The deployment of IGAD Monitoring and Verification Team like in Bor, Jonglei and Bentiu regions intended to monitor the implementation of Cessation of Hostilities $(\mathrm{COH})$ signed between conflict parties and the authorization of IGAD a Protection and Deterrent Force (PDF) from the region as its part. However, as one of the interviewee from the opposition side described that the overall success was achieved in 17 August 2015.

\section{The Resolutions and Implementation of Peace Agreement}

The resolution of the conflict started with the signing of the Agreement on the Resolution of the Conflict in the Republic of South Sudan by the parties to the conflict on Monday 17th August 2015 and by the President of the Republic of South Sudan Salva Kiir on Wednesday 26th August 2016, an agreement has eight chapters. In Chapter One they agreed to form Transitional Government of National Unity; Chapter Two: deal with Permanent Ceasefire and Transitional Security Arrangement; Chapter Three: decided on Humanitarian Assistance and Reconstruction; Chapter Four: concerning the issues of Resource, Economic and Financial Management; Chapter Five is about Transitional Justice, Accountability and Healing; Chapter Six: decided on Parameters of Permanent Constitution; Chapter Seven: talk about the formation of Joint Monitoring and Evaluation Commission (JMEC) to implement the agreement, and finally they agreed on the Supremacy of this Agreement and Procedures for Amendment of the Agreement (IGAD, 2015).

\section{Conclusion}

Therefore, the evidences show that the IGAD-led mediation team was used the power based approach mediate the parties in conflict during the peace talk. In consequence of, the warring parties were/are not happy by IGADled peace process and enthusiastic to implement the peace agreement. Because they considered the peace agreement was signed by the influence of international community. Consequently, as the conflicting parties are reluctant to be abide by and implement the peace agreement, the peace accord in brining sustainable peace in South Sudan is very contentious and it has also the prospect to be collapsed peace concord.

\section{Recommendation}

The researcher studied from the beginning of the peace process up to the initial stage of implementation of the peace agreement. Because the issue of implementation of the peace agreement is ongoing and it needs further 
study, the researcher couldn't cover the entire process of implementation of peace agreement in the study.

Therefore, the implementation of Peace Agreement relies on the commitment and political will of the warring parties. So the international community should exert pressure on both warring parties so as to speed up the implementation process of Peace Agreement because the South Sudanese are suffering by intense security problems and food crisis associated with the conflict up until now. Besides, the international community should exclude, those who are uncompromising and create impediment to the implementation of the Peace Accord, from the rank of Transitional Government of National Unity (TGONU). Because the evidences indicate that both belligerent parties leaders are not portrayed their political will and good faith to implement the Peace Concord.

On the South Sudanese side, the warring parties and other stakeholders should implement the peace agreement as they signed for the well-being and amelioration of their societies of South Sudanese rather than condemn and complain the international community's for imposed peace agreement. In addition, they should develop the culture of tolerance and peaceful means of conflict resolution rather than solving the dispute by military means; they should build up the strong national identity and sense of solidarity among the heterogeneous communities of South Sudanese by accepting their culture, ethnic, linguistic and religious diversity.

Moreover, they should establish strong institutions to run the country to the path of development and to ensure sustainable peace for their communities. And also they should enforce law to mitigate the pervasive corruption which create suspicious and lack of trust among communities on their leaders.

On the IGAD side the IGAD member countries should work hard in order to ensure the peace and security of their countries in particular and the region in general by putting aside their vying interest for regional power as well as they should follow the same route to solve any interstate and intra-state conflict that arise.

On the AU side, the AU has a mandate to intervene in the internal affairs of member countries conflicts. Therefore, it should look for the immediate solution to the conflict before escalating into violence and mass killing rather than contributing troops for peace keeping after the fighting breakout.

\section{Reference}

Abdelnour, S., Babiker, B., El Jack, A., Wheeler, D., McGrath, S., Branzei, O. (2008): Examining Enterprise Capacity: A Participatory Social Assessment in Darfur and Southern Sudan. Centre for Refugee Studies, York University: Toronto.

Abiy, Z., Alemayehu, W., Daniel, T., Melese, G., and Yilma, S. (September 2009): Introduction to Research Methods. Graduate Studies and Research Office Addis Ababa University.

Akol, D. Z. (2014): Inclusivity: A Challenge to the IGAD-Led South Sudanese Peace Process. THE SUDD INSTITUTE RESEARCH FOR A PEACEFUL, JUST and PROSPEROUS SOUTH SUDAN, JUBA, SOUTH SUDAN

AUCISS. (2014): Final Report of the African Union Commission of Inquiry on South Sudan, Addis Ababa, Ethiopia

Awolich, A. (2015): The Mediation Pendulum and the Challenges that Underlie the Peace Implementation in South Sudan. The SUDD INSTITUTE, Research for A Peaceful, Just and Prosperous South Sudan, Juba

Berg, B. L. (2001): Qualitative Research Methods For The Social Science 4th Edt. California State University, Long Beach

Berghof Foundation for Peace Support (2006): Sudan: Conflict Analysis and options for Systematic Conflict Transformation, Berlin

Blanchard, P. (2014): The Crisis in South Sudan. Congressional Research Service

Bruce, L. (2001): Qualitative Research Methods for Social Sciences 4th ed. California State University. Long beach, USA

Creswell, J. (2007): Qualitative inquiry \& research design: Choosing among five approaches (2nd ed.). New Delhi: Sage publication.

Daoud, M. (2012): Factors of Secession: The Case of South Sudan. A Research Thesis in Partial Fulfillment of the Requirements for the Degree of masters of Arts, Department of Political Studies, University of Saskatchewan, Saskatoon

Fok, M. (2014): South Sudan's Crisis: Weighing the Cost of the Stalemate in the Peace Process. The Sudd Institute, Juba, South Sudan

Getachew, Z. (2015): Tackling the South Sudan Conflict within a Complicated Regional Security Complex. The Southern Voices Network: Policy Brief, Wilson Center Africa Program

Gil, M. M. (2014): South Sudan: The Roots and Prospects of a Multifaceted Crisis, Policy Department, European Union, Belgium

HSBASSS (2016): The Conflict in Upper Nile State, Small Arms Survey, Maison de la Paix, Chemin EugèneRigot 2E, 1202 Geneva, Switzerland www.smallarmssurveysudan.org

IGAD (2014): Agreement on Cessation of Hostilities between the Government of the Republic of South Sudan 
(GRSS) \& the Sudan People's Liberation Movement/Army (SPLM/A In Opposition), Addis Ababa, Ethiopia.

IGAD (2014): Agreement on the Status of Detainees between the Government of the Republic of South Sudan (GRSS) \& the Sudan People's Liberation Movement/Army (In Opposition) (SPLM/A in Opposition), Addis Ababa, Ethiopia.

IGAD (2014): Agreement to Resolve the Crisis in South Sudan. Addis Ababa, Ethiopia

IGAD (2015): AGREEMENT ON THE RESOLUTION OF THE CONFLICT IN THE REPUBLICOF SOUTH SUDAN. ADDIS ABABA, ETHIOPIA

International Crisis Group (2015): South Sudan: Keeping Faith with the IGAD Peace Process, Africa Report No 228 Brussels, Belgium

Kothari, C. R. (2004): Research Methodology: Methods and Techniques (2nd. Ed) New Delhin: New Age International Ltd

Koos, C and Gutschke, T. (2014): South Sudan's Newest War: When Two Old Men Divide a Nation. GIGA focus German Institute of Global and Area Studies

Mogae, G. (2016): Report from the Chairperson of the Joint Monitoring and Evaluation Commission (JMEC) for the Agreement on the Resolution of the Conflict in the Republic of South Sudan to the African Union Peace and Security Council (PSC) Addis Ababa, Ethiopia

Robinson (1993): Real World Research: A Resource for Social Scientists and Practitioners. London: Black Well Publishers.

Palinkas, A., Horwitz, H., Green, A., Wisdom, P., Duan, N., Hoagwood, K. (2013): Purposeful Sampling for Qualitative Data Collection and Analysis in Mixed Method Implementation Research. New York, USA

Patton, M, Q. (2002): Qualitative Research and Evaluation Methods. Thousand Oaks, CA: Sage Publication.

Sabina Y., and Khan F. (2012):'Triangulation' Research Method as the Tool of Social Science Research.BUP JOURNAL, Volume 1, Issue 1 pp.154-164

Yohannes, T. (2015): Challenges for peace in South Sudan: Problems and Opportunities of Solving the Current Civil war, Dire Dawa University 